\title{
How Was Ibsen's Modern Drama Possible?
}

\author{
Narve Fulsås \\ University of Tromsø-The Arctic University of Norway \\ narve.fulsas@uit.no \\ Tore Rem \\ University of Oslo \\ tore.rem@ilos.uio.no
}

\begin{abstract}
One of the major renewals in the history of drama is Henrik Ibsen's "modern tragedy" of the 1880 s and 189os. Since Ibsen's own time, this renewal has been seen as an achievement accomplished in spite, rather than because, of Ibsen's Norwegian and Scandinavian contexts of origin. His origins have consistently been associated with provinciality, backwardness and restrictions to be overcome, and his European "exile" has been seen as the great liberating turning point of his career. We will, on the contrary, argue that throughout his career Ibsen belonged to Scandinavian literature and that his trajectory was fundamentally conditioned and shaped by what happened in the intersection between literature, culture and politics in Scandinavia. In particular, we highlight the continued association and closeness between literature and theatre, the contested language issue in Norway, the superimposition of literary and political cleavages and dynamics as well as the transitory stage of copyright.
\end{abstract}

\section{Keywords}

Ibsen - tragedy - printed drama - The Modern Breakthrough - Georg Brandes national literature - copyright

On several occasions, Franco Moretti has highlighted the reverse relation between the geography of the novel and the geography of "modern tragedy." Ibsen, whom he holds to be the key figure in this respect, is seen as belonging "to a Scandinavian culture which had been virtually untouched by the novel," 
and as causing the most heated controversies exactly in the "great powers" of novelistic production, France and England (Moretti "Moment" 39). But another cultural power became the gateway to the world of modern tragedy and modern tragic theory: "Kierkegaard, Ibsen and Strindberg achieved world-historical significance only through German mediation" (Moretti "Moment" 40; Moretti Distant 23-26).

Is it possible to answer more precisely why the "tragic" renewal of drama originated in the Nordic region of Europe and why a Norwegian author in particular came to be the key figure? Aiming at a kind of all-encompassing explanation would be futile, but at least we can try to identify the conditions that made Ibsen possible. In received narratives these conditions have been overwhelmingly associated with Ibsen's departure from Norway in 1864 and his 27-year stay in Italy and Germany, depicted as a liberating "exile" from the provincial conditions at home. We will, on the contrary, argue that although Ibsen did experience restrictions at home, not least a limited social space, he continued to belong to Norwegian and Scandinavian literature and that it was the changing conditions of this literature that fundamentally shaped his literary trajectory. ${ }^{1}$ Here, we will emphasise the changing relations of literature to theatre, language, politics, markets and copyright.

\section{Literary Theatre}

It is slightly exaggerated to claim that Scandinavia was "virtually untouched" by the novel at the time of Ibsen's dramatic debut in $185^{\circ}$. As Moretti himself has documented, Denmark stood out with a remarkably high level of translation activity, covering a very broad spectrum of imaginative literature, in the early nineteenth century (Moretti Atlas 174-185). Denmark also got its own native novelists during its literary "Golden Age" at the time. In Norway, after 400 years of union with Denmark had ended in 1814, Danish continued to be the written language and Norway continued to belong to the Danish literary circuit. Danish novelists therefore came to Norway as well, and so did the European novel on a wave of Danish translations in the 1830s (Tveterås Bokens 118-25). The Norwegian domestic production, however, was delayed. The first Norwegian "bourgeois" novel appeared in 1854-55 and the development of the novel into a full-blown modern, literary genre only happened from the 1870 (Andersen 246). And although the novel had arrived by the middle of the century, it did not

1 See Fulsås and Rem for a full account of the arguments in this paper. 
displace the drama. Plays continued to be popular reading matter and poetry and drama were clearly the "high" and serious genres by the middle of the century. Not that many native dramas were written, but this was a reflection of the very low level of domestic literary production in general.

The efforts at creating "Norwegian theatres" in the 1850 s contributed to strengthening the connection between literature and theatre. Their aims were to replace Danish actors and language with Norwegian and to stimulate the production of national drama. Ibsen was part of this project in Bergen and Kristiania (Oslo) throughout the 1850 s and the beginning of the 1860s. Most of his own national dramas in this period were also published. This encouraged Ibsen all from the start to write dramas in one version only, intended both for reading and performance. Furthermore, the theatre project did not just have a national side but also an artistic one. While the "other" of the national side was Danish, the other of the artistic side was the French hegemony over European theatre. Why was there a general sense of decline in the theatre, Ibsen asked in 1857? Those to blame, he thought, were the dramatic authors and particularly the output from France, "these in technical terms perfect pieces of art that annually emanate from the Parisian authors' workshops and that to such a sad degree contribute to promoting virtuosity at the expense of art,- - these laceworks that are calculated only to create effect through the 'delivery of lines' cannot but degrade art to a lower region — that of sensation" (Ibsen "Wiehe"). ${ }^{2}$ It was, then, both a national and an artistic duty to contribute to the literary elevation of the theatre.

This open space of theatrical renewal contracted, however, as box office considerations increasingly took over. This was one reason why Ibsen left Norway, and also why he directed his attention to the book market when he moved to the Danish publisher Gyldendal. Ibsen's first two books with Gyldendal, the verse dramas Brand (1866) and Peer Gynt (1867), made his breakthrough in the Scandinavian book market. He then returned, encouraged by his publisher, to write for theatre with The League of Youth (1869). This publication initiated the pattern of all his later play productions. At first, both Ibsen and his publisher intended to follow the conventional pattern of submitting the play to theatres first, and then to publish it only after the performance. There were economic reasons for this order as theatres would pay less, if at all, for published plays. The order was, due to various technicalities and the schedule which seemed

2 When indicated, we have quoted from an English translation of Ibsen's letters (Sprinchorn); in other cases, translations are ours and cited from the electronic edition of Ibsen's letters available on ibsen.uio.no. Other translations from Scandinavian and other non-English sources are also ours, unless otherwise noted. 
to suit Ibsen and his publisher best, reversed, however. Ibsen's growing book market potential and the consolidation of his Scandinavian home market by mutual agreements on copyright by the late 1870 cemented the pattern. Theatres eventually had to accept that the book was given priority and was out before performance. This new "literary hegemony" over theatre had several implications. Many of the spectators arriving in theatre would have read the play before seeing it performed and could compare their experiences. The same was true for critics. And if a theatre chose not to put on a play, like most did with Ghosts, it was there for reading and the decision could be challenged, as indeed it was.

Nordic developments in this area differed sharply from what was happening in major European literatures at the time. The bibliography of Danish publications, Dansk Bogfortegnelse, listed Ibsen in the sub-category "Danish plays," which again belonged to the main category "dramatic poems." Native plays far outnumbered translated ones in this sub-category and, in terms of authors, the number of playwrights grew faster than the number of "lyrical poets" or even novelists from the 1860 s to the 1880 s. In Germany, by contrast, a trade magazine in 1874 stated that "whoever wants to put a German publisher in a chilly mood, will offer him a collection of plays ... [T] he drama is for the stage, not for reading" (Magazin für den deutschen Buchhandel, vol. 1, 107, quoted in Wittmann 149). In Britain, theatre manuscripts were only printed in a limited number of acting editions, cluttered with technical abbreviations. "Books" and "plays" were generic dichotomies and by the 1880 s, the printed drama had more or less collapsed (Eliot 50). When Henry James in 1889 pronounced judgment on the state of contemporary English drama, claiming that "the sun of the drama has set" (42), he let his mouthpiece note that "to begin with, you can't find it - there's no text" (40). The withholding of British plays from the book market was presented as one of the clearest signs of the theatre's moribund state. A later theatre historian, Erika Fischer-Lichte, states unambiguously: "As the nineteenth century progressed, the situation in theatre across Europe grew more and more desolate. By about 1880, the literary level of theatre had reached an all-time low" (244).

It is fair to say that the contemporary printed play reappeared with Ibsen. It was only when he was appropriated by local agents intent on bringing about a literary renewal of the theatre and a revival of the native drama that he experienced his breakthrough in German and English from the late 1880s on. If the revival of the printed play in English is largely attributed to George Bernard Shaw, there can be no doubt about the importance of Ibsen's example to Shaw's fusion of dramatic and novelistic conventions, all down to the most minute details of typing and price. 
The literary fields of England and France might have been more advanced than the Scandinavian one in terms of differentiation and the hierarchization between genres and institutions. In France, according to Pierre Bourdieu's account, authors such as Baudelaire and Flaubert responded to the expanding markets by claiming that recognition by peers and other specialists was superior to that by the uninitiated public. From this distinction between the aesthetic value of a work and its commercial value a "literary field" emerged, structured by the opposition between a sector of autonomous, restricted production and a sector of large-scale production, represented primarily by the commercially successful boulevard theatre authors. Towards the end of the century, this hierarchy between genres tended to be replaced by opposition between experimental and commercial sectors inside each genre (Bourdieu 113-21). However, no renewal of the drama emerged from within such a structure; it emerged from the more "backward," less differentiated Scandinavian environments, where theatre and literature had preserved a closer relationship. When the French avant-garde theatre appeared by the late 1880 s, it was not by itself able to renew native French drama, as it largely had to rely on import, not least Ibsen and Strindberg. In Britain the emergence of an "independent" theatre sector was even more closely interwoven with the overall Ibsen campaign.

\section{Contested Language}

Specific to Norway among Scandinavian countries (along with Denmark and Sweden) was the "language question." In the new independent Norwegian state of 1814, Danish was, as already noted, the inherited vernacular language - the language of the Bible and the law. Attempts at making it a common property by naming it "Dano-Norwegian" was fiercely resisted in Denmark and was given up. From the middle of the century a transition from vernacular Danish to national Norwegian was called for, but along two conflicting lines. One went for "Norwegianizing" the existing language by introducing Norwegian words where they differed from Danish and by spelling reforms adjusting the written language to "Norwegian pronunciation," that is, the pronunciation of the urban educated and business classes as it had emerged in the seventeenth century. The other strategy was more radical: to construct a new written language based on rural dialects and with reminiscences of Old Norse. Ibsen and Bjørnson opted for a moderate version of the first strategy, the only strategy compatible with going to a Danish publisher. This move was not consistent with the national theatre strategy, but it had apparent advantages. A Danish publisher gave Norwegian authors access to the Danish market while adding 
prestige to a publication in the Norwegian market. And the Danish publisher soon experienced that the new Norwegian generation became the leading one in the Nordic countries and spearheaded Gyldendal to the position of the leading literary publisher in all of Scandinavia.

The contestation between vernacular and national circulation (Beecroft 96-8) had a profound impact on Ibsen's literary achievement. It put him in the middle of a tension between assimilating to a dominant language and literature, on the one hand, and joining the nationalizing efforts, on the other. Ibsen resisted enrolment on either side. He would insist on the existence of a Norwegian language and on being a Norwegian author, but would usually abstain from using national designations when referring to his own language. After moving to Gyldendal, Ibsen stated that Copenhagen was "our common literary capital" and he would more than once claim that he entertained the idea of moving there. But he never did, and there are several examples of him turning forcefully against what he perceived to be Copenhagen arrogance and ignorance of what was going on in the other Nordic countries; not least did he criticise the Danish critic Georg Brandes for this in the 1870 (Ibsen Letters 148, 155). From the beginning Ibsen had experienced criticism in Denmark for his use of Norwegian words. As more Norwegian authors were published in Denmark, they were regularly reminded that they were on someone else's linguistic ground and ought to comply with the owner's rules and regulations (Tveterås Norske 410). Ibsen strongly supported younger colleagues facing such criticism. In 1878 he wrote to one of them, Laura Kieler: "There is so much inane correctness in Denmark. Be on your guard against it and similarly be on your guard against acting like a Dane, do not be ashamed of continuing to think and feel in Norwegian; one can obviously make you un-Norwegian, but you will not therefore become Danish" (Ibsen "Kieler").

There was a heavy essentialist rhetoric accompanying the Norwegian language movement, but the effect of the postcolonial linguistic situation was the exact opposite: language became thoroughly politicised. To a Danish or Swedish author language might have been "natural"; to Norwegian authors it was de-naturalized and a matter of choice whatever particular strategy they opted for. The Royal Theatre in Copenhagen was set to protect the "purity" of the language against Norwegian deviations; the Norwegian theatres were set to reform it. In Ibsen this situation fostered disrespect for Danish "inane correctness." A fraught linguistic situation was, writes Terry Eagleton with reference to Ireland, favourable to a "flourishing native modernism as opposed to one imported from abroad" (24). Irish writers certainly recognised a similarity with Norwegian ones. Not least did Joyce identify with Ibsen and he would see his own freedom from English conventions as a major source of his talent. 


\section{From Anti-Politics to “The Literary Left"}

Ibsen's political attitudes are among the most bewildering and seemingly contradictory aspects of his intellectual life. It is our contention that Scandinavian politics, and Norwegian-Danish politics in particular, played a vital part in facilitating what was to become "The Modern Breakthrough" in Scandinavian literature, with A Doll's House (1879) as one of its first major outcomes. It is also our contention that Ibsen's politics throughout most of the 1870 s put him on the side-line of the literary-political dynamics leading up to "The Breakthrough," and that when he joined it, it meant a major reorientation of his politicalliterary identity.

Ibsen, like most Norwegian intellectuals, was a supporter of the PanScandinavian movement and was upset by the lack of Scandinavian military solidarity in 1864 when Denmark lost the duchies of Schleswig and Holstein to the allied forces of Prussia and Austria. His reaction to defeat and disillusionment was hostility to politics. One of the attractions of Rome, he claimed, was that it offered him an asylum from politics. After the upheavals of the 1848 revolution, the Catholic Church resisted all kinds of changes and managed for a time to stay outside the new Italian state of 1860 . Ibsen appreciated this situation, but in 1870 the Church State fell. Rome was taken over by the Italian nation state and the idyll was over: "They have finally taken Rome away from us human beings and given it to the politicians," he complained to Georg Brandes, "[w] here shall we take refuge now? Rome was the one sanctuary in Europe, the only place that enjoyed true freedom - freedom from the tyranny of political freedom" (Ibsen Letters 106).

To Ibsen the modern state was a machine for equalization and homogenization that threatened to eradicate individuality: "[T] he state is the curse of the individual," as he once put it to Brandes (Letters 108). Living in Dresden during the Franco-German war of 1870-71 he likened his own situation to that of the beleaguered population of Paris. He virtually fled from the consolidation of state power across the European continent, only to be relentlessly caught up, first in Rome, then in Dresden when Saxony in 1870 joined German unification under Prussian leadership. When the family moved southwards again in 1875, this time to Munich, Ibsen complained that in northern Germany the state and politics "have subjected all forces to its service and appropriated all interests" ("Gosse").

There are similarities between Ibsen's anti-politics and the stance taken by writers like Baudelaire and Flaubert in this period. The failure of the revolution of 1848 and the experiences of the Second Empire led them, writes Bourdieu, to a "disenchanted vision of the political and the social world" and 
an "undifferentiated condemnation of all those who sacrifice to the cult of good causes" (59, 81). However, there are significant differences as well. For Flaubert and Baudelaire, their disenchanted vision led them to a "heroic" rejection of all signs of social recognition, although ambivalently (6o-63). Ibsen rather sought such recognition and this was one of the issues at stake when he fell out with his contemporary Bjørnstjerne Bjørnson. In this period, Bjørnson reacted quite the opposite of Ibsen, immersing himself in domestic politics and eventually becoming a leading figure in the opposition against the royal government. When Bjørnson tried to persuade Ibsen to join a common boycott strategy in the event that they were offered royal orders or decorations, Ibsen refused. He even put much effort into acquiring the first two or three of such awards.

Ibsen's anti-politics also led him into a more and more outspoken conservative position as the $187 \mathrm{os}$ progressed. The League of Youth (1869), portraying a liberal politician many found reminiscent of Bjørnson in the least flattering manner, contributed to bestowing a conservative identity upon him. Ibsen did little to disturb this impression. In his letters, he would declare that "I loyally stand by the government and support it with my pen and all my abilities" (Letters 105), and that he sided with the guardians of order, only regretting that the government was too soft on the opposition when they allowed people like Bjørnson and other liberal leaders to operate freely (129). After meeting Ibsen in Dresden in 1872, Brandes reported that the playwright considered all parliamentary politicians - explicitly not a man like Bismarck — to be liars, hypocrites, and dilettantes for their outdated preoccupation with political matters (Forceldrene 15-17). Believing strongly in a monarchy that would uphold an aristocratic spirit and destroy the liberals, he was furious with Bjørnson's republicanism. Writing home, Brandes complained: "[Ibsen's] hatred of false struggles for freedom is on its way to repress his interests in true struggles for freedom. If he were not my friend, he would be my enemy" (20). As late as October 1879, less than two months before the publication of $A$ Doll's House, Brandes stated in a letter that Ibsen "in recent years has been courting the arch-conservatives" (Correspondance 200).

At this time a "Literary Left" had formed in Denmark and Norway. In early 1875 Bjørnson published his two contemporary plays, A Bankruptcy and The Editor. Georg Brandes hailed them as the introduction of a new era: "Finally! Finally it seems that we in the Nordic countries are close to getting a cycle of plays in which those two great powers, the now and reality, are being respected and allowed to come into their own right" ("Literatur" 241). These plays helped bring together Brandes and Bjørnson, who up until then had been rather hostile to each other. Political cleavages became superimposed on literary ones 
towards the end of the decade. In Norway, the liberal parliamentary opposition grew stronger throughout the 1870 s and by 1884 the King was forced to appoint a government from the parliamentary majority. Exactly the same fight with the same constellations was going on in Denmark, although there a parliamentary system was postponed for another couple of decades.

In 1879 the polarization of the political struggle led to more or less formal alliances between the political Left and what in the course of this year came to be known as "The Literary Left." In Norway, this alliance was already personified in Bjørnson. In Denmark, it involved Georg Brandes' brother Edvard running as a liberal candidate for parliament in Copenhagen. The political cleavages which split the state thereby contributed to polarizing every aspect of culture in the two countries. The political situation was different in Sweden, but a similar grouping emerged there with the "young Sweden" and the "eighties" generation of authors (the attitalisterna). These developments were, we should note, contrary to what at the same time took place in Germany, where Ibsen was living. There, Bismarck dismissed his national-liberal allies, started to rely on catholic and conservative parties and effectively blocked the development towards parliamentary rule.

From the middle of the 1870 s Ibsen seems to have sensed that the times were changing and that the centre of gravity was moving leftwards. One indication is that in 1877 he addressed an appeal for an increased state grant, something which he had been allowed since 1866, to the opposition, not the government (Ibsen "Sverdrup"). In literary terms, the first sign of a renewal was Pillars of the Community (1877). The authors of the Literary Left were far from impressed, however. Georg Brandes was rather positive, while Edvard was disappointed. Ibsen was "so anxious not to cause provocation," he thought, "that there is no greatness to his play" (Brandes and Brandes 2, 5-6). The novelist J.P. Jacobsen remarked that Ibsen "is only half his own self and has forgotten what was written between the lines in Catilina" (Brandes and Brandes 3 , 135-136). The "uplifting" character of Pillars of the Community was a surprise to those who had become accustomed to the fierce satire of Brand and Peer Gynt.

Pillars of the Community is social criticism in the comic mode, the social order being restored and counsellor Bernick forgiven for his sins against family and society at the end. Ibsen's propensity for tragedy had so far found expression only when dealing with medieval and aristocratic subjects. When he had moved to contemporary matters, he had resorted to moralizing comedy, as in The League of Youth, or to versified satire, as in Brand and Peer Gynt. Ibsen had struggled to overcome verse and was proud of the prosaic "realism" of Emperor and Galilean (1873). He was also pleased with what he considered to be a consis- 
tently realist dialogue without monologues and asides in The League of Youth. By 1877, then, he had achieved both the writing of realist, "de-idealized" prose tragedies on historical topics, and of realist prose comedies on contemporary topics. What he had not done, and not even conceived, it seems, was a realist, contemporary prose tragedy.

According to the textual evidence which has survived, the first time such a thing appears is in the first notes to what was to become A Doll's House, dated 19 October 1878 and entitled Optegnelser til nutids-tragedien ("Notes for the tragedy of modern times"). It is hard to find a more pertinent context for this breakthrough in treating contemporary middle-class life with the radical seriousness of tragedy than the literary-political dynamics unfolding in Scandinavia at the time. These dynamics had the characteristics of an emerging "literary field," opposing "old" to "young," bourgeois accommodation to true art, recognition by peers to recognition by the ordinary audience. By 1879 , the Brandes brothers had redirected their hopes towards new writers. Edvard took care of August Strindberg in Sweden while in June 1879 Georg Brandes wrote to the new Norwegian novelist Alexander Kielland: "The two old ones [Bjørnson and Ibsen] are laboriously working to get loose; show that you have a lead" (Brandes and Brandes 4, 256). In August he continued: "Your danger would be to be accepted by the ruling philistinism ... What is incredible in this respect has of course happened with Ibsen in Norway, who, as cutting as he is and was, has been appropriated and has let himself be appropriated. Be an artist completely!" (263).

A Doll's House changed these perceptions and with his next play, Ghosts, Ibsen moved yet further, radically challenging what was appropriate to put on display in the theatre. At first no theatre director dared produce it, and even the book publication caused an outcry. After Ghosts, Georg Brandes could not quite comprehend why Ibsen had abandoned his "relative position of cautiousness" but thought it might be "in order not to lose his advanced position" (Brandes and Brandes 3, 344). He did not particularly like Ghosts: "[W]e need works which will persuade and conquer," he wrote to Bjørnson, "not that provoke and frighten" (ibid. 4, 147-8). But Ghosts was useful to him because it definitely enrolled Ibsen in his "literary party," as he called it. Brandes publicly acknowledged Ibsen for having "risked all of his patiently and slowly won authority, his goodwill among the public, almost his entire bourgeois reputation". Ghosts might not, in spite of its enormous significance, be his most perfect drama, Brandes thought, "but it is the most noble deed of his literary life" (Brandes, "Gjengangere"). At this time Ibsen himself adopted a rhetoric of moving boundaries. Ghosts might in several respects have been "rather daring," he wrote to a Danish journalist: "But it seemed to me that now was the time when some 
boundary posts had to be moved. And for that undertaking an older writer like myself was more fitted than the many younger authors who might desire to do something of the same nature" (Letters 203).

With A Doll's House and Ghosts Ibsen reinvented himself as dramatist, changed his political identity and reconquered the literary hegemony which had been challenged by the late 1870 . Not that he was simply subdued by the logic of the field; it enabled him to transcend aesthetic restrictions and when he entered into this dynamic he gave it a momentum it would not have achieved without him. A Doll's House and Ghosts "radicalized" literature far beyond anything Brandes had expected when in the early 1870 s he had called for a literature which subjects problems to debate. And having reconquered his leading position, Ibsen immediately set out to distance himself from Brandes and his literary party. An Enemy of the People was Ibsen's contribution to the dissolution of The Literary Left and with The Wild Duck he moved completely away from "social art" into a position from which he was able to dictate his own rules for the rest of his career.

\section{Bestseller}

The field logic of The Modern Breakthrough served, in other words, to expand the space of literary possibilities. At the same time, it was highly effective in "making the market disappear" (Bourdieu 81), concealing the discrepancy between avant-garde rhetoric and actual circulation. Ibsen was at this time already a well-established bestseller; his publishing history from the 1860 s is a history of his publisher almost systematically underestimating the market potential of his leading author. This underestimation culminated with A Doll's House. The publisher printed a record high first edition of 8000 copies, but he immediately had to rush out new editions; in its first year, $A$ Doll's House had been printed in a total of 13,500 copies. This is not to say that the commercial success of $A$ Doll's House was a surprise to its author and publisher. Shortly before publication, Ibsen wrote to his publisher that "[s]ince this work deals with problems of a very topical nature, I think it will be in great demand and that we risk nothing by printing a pretty large edition" ("Hegel"). His publisher was a cautious Christian, and he did not like the ending of $A$ Doll's House. Even so, he immediately predicted that the play would be a success in the theatre. He told Ibsen that the head of The Royal Theatre in Copenhagen "clearly sees that he here has a play which will bring the theatre a substantial income" ("Hegel"). He was proven right as $A$ Doll's House was the success of the season in both Kristiania and Copenhagen. 
In the 1880 s the market stabilised and Ibsen was regularly printed in first editions of 10,000 copies, increasing to $12-15,000$ by the end of the 1890 s. His plays continued to be the event of the season in theatre as well, and in the Norwegian capital Kristiania very often among the three most frequently performed. This happened in a completely commercial enterprise which always had to bring German farce and proven boulevard staple from Paris alongside the classics and contemporary Scandinavian drama. As for books, 10,000 is a large edition for this kind of literature in any European country, then and now, but it is quite remarkable for two additional reasons. The first is that Ibsen's primary home market was Denmark and Norway, with a total population of only 4 million inhabitants. The other is that his books were of high material quality, were expensive and never came in cheap editions (until the turn of the century).

The new literature, then, emerged together with an expanding readership and theatre audience, not ahead of it. Ghosts, too, did well as a book, but its rejection by leading theatres has quite misleadingly been made into the general rule, the iconic instance of controversy, rupture, and forced "exile" from "backward" Scandinavia. The reason for this, we will suggest, is precisely that such controversy conforms to the logic of the field, opposing literary value to economic value, while Ibsen as one of the commercially most successful authors of his time violates this logic. Ghosts caused the playwright financial loss, but for exactly that reason it took on such an enormous symbolic significance and earned the playwright the invaluable reputation of being an uncompromising, persecuted author.

Ibsen had no interest at all in repeating the Ghosts controversy and with $A n$ Enemy of the People he managed to negotiate a balance between winning back his old audience and maintaining his new-won "avant-garde" status. The play could stand out as a militant defense of the uncompromising author while at the same time being intended, as he wrote to his publisher, to appease theatre directors and their bourgeois audiences: "It will be a very peaceable play this time, one which may safely be read by the state councilors and the merchants and their ladies; and the theaters will not have to recoil in horror from it" (Letters 206).

How is Ibsen's commercial success to be explained? Literary quality alone will not do, since the other Norwegian "golden age" authors at the time, Bjørnson, Jonas Lie, Alexander Kielland, were also well ahead of Scandinavian contemporaries like J.P. Jacobsen or August Strindberg in terms of print runs. The most likely reason for the difference is that literature became an unexpected and welcome source of prestige to the young Norwegian nation in its efforts to overcome the age-old cultural hegemony of Denmark and the new political 
hegemony of Sweden. The extraordinary attention which literature enjoyed in Norway at this time evokes the remarks of Franz Kafka on the public role of literature in small nations. "The pride which a nation gains from a literature," he wrote, could be felt even stronger in the case of restricted literatures where the number of experts would be fewer, but where literature would be a concern of "the people," absorbing "everyone no less than a matter of life and death" (Kafka 148-50). The extraordinary status of authors and literature in Norway was noticed on many occasions by Norwegian authors themselves. Jonas Lie reported from Stuttgart in 1879 that literature there was a minority interest and that authors had a socially and financially inferior position compared to the "blessed" conditions at home (Lie 478-9). Alexander Kielland stated from Paris in 1888 that "in my opinion there is no nation today where people read as many books as in Scandinavia" (Kielland 237).

It was, then, the intersection of the "law of the field," the polarization of the political field and the national role of literature which together facilitated The Modern Breakthrough and its foremost outcome, Ibsen's “modern tragedy." A field logic alone could not have made it, and a literary avant-garde or minority theatre in Scandinavia would not have been possible. The rhetoric of rupture and provocation was highly productive in overcoming aesthetic restrictions and not least in shaping the historical legacy of The Modern Breakthrough. But it has been far too uncritically reproduced in later scholarship and it is incompatible with the evidence of print runs, theatre attendance, incomes and social recognition.

\section{The Transitory Stage of Copyright}

The internationalization of Ibsen's drama in the late nineteenth century was decisively shaped by the transitory stage of copyright. When Ibsen made his debut in 1850, the existing regulations were still those from the absolutist days of the eighteenth century. In 1876, a modern law on authors' rights was passed in Norway and by the end of the decade mutual Scandinavian agreements consolidated Ibsen's Scandinavian home market: from now on, he was treated as a native author in all three countries. However, the Scandinavian countries, as literary import countries, decided not to join the Bern convention of 1886, Norway joining as the first in 1896 and Denmark only in 1903. In legal terms a Danish author, Ibsen was unprotected outside Scandinavia during all his career.

An assessment of the importance of this legal situation invites counterfactual reasoning and must be conjectural. One effect is rather straightforward, however: the simultaneous publication of Ibsen's plays in several European 
capitals in the 1890s-perhaps the first truly synchronised "world events" of "world literature" - was a product of the copyright situation. In order to protect their interests in their domestic markets, William Heinemann in London and Samuel Fischer in Berlin issued editions simultaneously with the Copenhagen original. This secured Ibsen incomes: they had to pay him, not for copyright but for early delivery of sheets.

Otherwise, the copyright situation seems to have had both enabling and restricting effects. By 1876, Ibsen put some effort into becoming a "German author," commissioning his own translations and entering the German authors association to deal with his interests in the theatre market. The fate of Pillars of the Community and A Doll's House in Germany dealt blows to this strategy. Ibsen could not stop "pirates" from taking market shares and felt forced to make an alternative ending to $A$ Doll's House, while also experiencing that the cheap German edition of the play competed successfully with the original in Denmark. When the Scandinavian market was consolidated at this time, this contributed to Ibsen directing his attention primarily towards the Scandinavian market again in the early 188os, exactly when The Modern Breakthrough was unfolding. In the first half of the 188 os there was little interest in Ibsen in Germany, and Edmund Gosse, who had discovered the "poetic" Ibsen of Love's Comedy, Brand and Peer Gynt, had given up his Ibsen campaign by 1880 and made no further efforts to introduce or report on the author of $A$ Dolls' House and Ghosts. Ibsen's new mediator in Britain, William Archer, also initially thought that these plays would never be possible on English stages. This prompts the question whether something like Ghosts, which was soon made into a stage success by several touring companies in Scandinavia and performed even at The Royal Theatre in Stockholm, could have been written anywhere else in Europe.

In the next phase of development, when Ibsen started to take off in Germany and then in Britain and France from the late 1880s, the lack of protection might have been beneficial to the circulation of his works, though not to his incomes. At home, Gyldendal and Ibsen used copyright to restrict circulation in the book market; they prohibited translations into Swedish and issued expensive books only. This was sensible enough given the high sales of the costly editions in Norway and Denmark. Outside Scandinavia, the lack of protection at the same time demonstrated the market potential of a cheap Ibsen. Reclam soon took up Ibsen in their extremely low-priced Universal-Bibliothek. By 1890, they had already printed 16 Ibsen titles in a total of 494,00o copies; in 1900, 19 titles in 1,457,000 copies (Keel 136, 140). In Britain, the first concerted publishing campaign came with Ibsen being launched in the Newcastle publisher Walter Scott's Camelot Series, a cheap "prose library for the people" in 1888. Ibsen sold very well and after four years Archer estimated that something like one 
hundred thousand of Ibsen's prose dramas had been bought by the Englishspeaking public: "Is there a parallel in the history of publishing for such a result in the case of translated plays?" (Archer 308).

Ibsen was effectively introduced as reading matter in German and English as a cheap, "contemporary classic" for "the people." Only then did he "ascend" to more upmarket, modern and cosmopolitan publishers like Fischer and Heinemann. This resulted in Ibsen circulating both high and low, as cheap and expensive, as avant-garde and classic. Had his work been protected by copyright, Heinemann and Fischer would probably have issued him on a descending price scale, but would have hardly been able to reach the "mass reading" audiences of Reclam and Scott. How this would have affected the theatre is hard to decide; in Britain, contrary to Scandinavia and Germany, Ibsen remained in the minority, "independent" sector well into the twentieth-century anyway. But in the long run, it was vitally important for Ibsen's "world" standing that he experienced such a massive and rapid canonization as literature in the English language.

\section{Conclusion}

These efforts at contextualizing the Ibsen phenomenon should not at all serve to question his extraordinary talent. But his talent needed an ecosystem to unfold in and, contrary to standard accounts, we have wanted to highlight that Norway and Scandinavia provided a hospitable environment. It was no doubt important for Ibsen to live abroad; the Norwegian capital was small, the social space narrow, and Ibsen needed, unlike Bjørnson, to be away from factional struggle. Living abroad, he could enjoy the indifference of the immediate surroundings and a constantly growing attention at home. When he started to be directly implicated in controversies abroad, his position at home was so elevated that Norway again offered him the most favourable working conditions.

Throughout his career, Ibsen elaborated a poetics of distance which effectively made him the sovereign and self-contained centre of his literary achievement. Together with the avant-garde rhetoric of The Modern Breakthrough, this has served to obscure the vital role of his home market and the historical contingencies shaping his literary development. Empire models of literature have in some respects only cemented the impression of Scandinavia as a periphery lacking cultural resources, primarily offering restrictions to be overcome. In contrast, we have tried to suggest that there were important "advantages of backwardness," among which are what Moretti has identified as the late arrival of the novel and which is a reminder that different genres have different historical geographies. We have also highlighted how the expanding Scandinavian 
markets allowed increasing literary autonomy, and that the national stake in literature secured Norwegian authors extra attention. "Periphery" should, in other words, not be assumed to be only a position of disadvantage to a writer, and peripheral Scandinavia should be considered the central context of origin of Ibsen's "modern tragedy."

\section{Works Cited}

Andersen, Per Thomas. Norsk litteraturhistorie, 2nd ed. Oslo: Universitetsforlaget, 2012. Archer, William. "The Mausoleum of Ibsen." In Egan, 304-12.

Beecroft, Alexander. "World Literature Without a Hyphen." New Left Review 54, 2008, 87-100.

Bode, Dietrich (ed.). Reclam. 125Jahre Universal-Bibliothek 1867-1992. Stuttgart: Philipp Reclam, 1992.

Bourdieu, Pierre. The Rules of Art: Genesis and Structure of the Literary Field. Trans. Susan Emanuel. Stanford: Stanford UP, 1996.

Brandes, Georg. Correspondance de Georg Brandes. Vol. 3. Ed. Paul Krüger. Copenhagen: Rosenkilde and Bagger, 1966.

Brandes, Georg, “Georg Brandes om 'Gjengangere'” Dagbladet no. 2, 3 Jan. 1882.

Brandes, Georg. "Literatur. Bjørnstjerne Bjørnson: 'En Fallit' og 'Redaktøren'." Det nittende Aarhundrede 1875, 241-45.

Brandes, Georg. Breve til Forceldrene 1872-1904. Vol. 1. Ed. Morten Borup and Torben Nielsen. Copenhagen: Reitzel, 1994.

Brandes, Georg and Edvard Brandes. Georg og Edv. Brandes brevveksling med nordiske forfattere og videnskabsmeend, vols. 2-4. Ed. Morten Borup. Copenhagen: Gyldendal, 1939-1940.

Eagleton, Terry. "An Octopus at the Window." London Review of Books $33: 10$ (2011), 2324.

Egan, Michael (ed.). Ibsen: The Critical Heritage. London: Routledge \& Kegan Paul, 1972.

Eliot, Simon. Some Patterns and Trends in British Publishing 1800-1919. London: The Bibliographical Society, 1994.

Fischer-Lichte, Erika. History of European Drama and Theatre. Trans. Jo Riley. London: Routledge, 2002.

Fulsås, Narve, and Tore Rem. Ibsen, Scandinavia and the Making of a World Drama. Cambridge: Cambridge up, forthcoming.

Hegel, Frederik Vilhelm. “Letter to Ibsen." 12 Nov. 1879. The National Library, Oslo, Letter Collection 200.

Ibsen, Henrik. "Anton Wilhelm Wiehe" (1857). http://www.ibsen.uio.no/SAK_ P18571213Anton.xhtml. 15 Oct. 2016. 
Ibsen, Henrik. "Letter to Edmund Gosse," 10 Mar. 1875. http://www.ibsen.uio.no/BREV _1871-1879ht\% 7 CB18750310EGo.xhtml. 15 Oct. 2016.

Ibsen, Henrik. "Letter to Frederik V. Hegel," 2 Sep. 1879. http://www.ibsen.uio.no/BREV _1871-1879ht\%7CB187909o2FH.xhtml. 15 Oct. 2016.

Ibsen, Henrik. "Letter to Johan Sverdrup," 4 Feb. 1877. http://www.ibsen.uio.no/BREV _1871-1879ht\%7CB18770204JS.xhtml. 15 Oct. 2016.

Ibsen, Henrik. "Letter to Laura Kieler," 26 Mar. 1878. http://www.ibsen.uio.no/BREV _1871-1879ht\% 07 CB18780326LK.xhtml. 15 Oct. 2016.

Ibsen, Henrik. Letters and Speeches. Trans. and ed. Evert Sprinchorn. London: MacGibbon \& Kee, 1965 .

James, Henry. "After the Play." New Review, vol. 1, 1889, 30-45.

Kafka, Franz. Diaries, 1910-1923. Ed. Max Brod, trans. Joseph Kresh, Martin Greenberg and Hannah Arendt. New York: Schocken Books, 1976.

Keel, Aldo. "Reclam und der Norden. Autoren, Titel, Auflagen 1869-1943." In Bode 13247 .

Kielland, Alexander L. Brev 1869-19o6, vol. 2. Oslo: Gyldendal, 1969.

Knudsen, Jørgen. Georg Brandes. I modsigelsernes tegn. Berlin 1877-83. Copenhagen: Gyldendal, 1988.

Lie, Jonas. Brev 1851-19o8, vol. 1. Ed. Anne Grete Holm-Olsen. Oslo: Novus, 2009.

Moretti, Franco. Atlas of the European Novel 1800-19oo. London: Verso, 1998.

Moretti, Franco. Distant Reading. London: Verso, 2013.

Moretti, Franco. "The Moment of Truth." New Left Review 159, 1986, 39-48.

Tveterås, Harald L. Norske forfattere på danske forlag. Den norske bokhandels historie, vol. 2. Oslo: Cappelen, 1964.

Tveterås, Harald L. Bokens kulturhistorie. Den norske bokhandels historie, vol. 3. Oslo: Cappelen, 1986.

Wittmann, Reinhard. Buchmarkt und Lektüre im 18. und 19. Jahrhundert. Beiträge zum literarischen Leben 1750-188o. Tübingen: Max Niemeyer, 1982. 